\title{
TINGKAT KESUKAAN PANELIS TERHADAP PENYEDAP RASA ALAMI HASIL SAMPING PERIKANAN DENGAN EDIBLE COATING DARI KARAGENAN
}

\author{
M. Alaksmar Djohar ${ }^{1}$, Samuel Marthen Timbowo ${ }^{2}$, Feny Mentang ${ }^{2}$ \\ ${ }^{1)}$ Mahasiswa pada Program Studi Teknologi Hasil Perikanan FPIK Unsrat Manado \\ ${ }^{2)}$ Staf pengajar pada Program Studi Teknologi Hasil Perikanan FPIK Unsrat Manado \\ Email: fmentang@unsrat.ac.id
}

\begin{abstract}
Product of fish processing industry called juice water contain a lot amino acid compound. The aim of this study was analyze sensory characteristic of natural condiment made from" juice water" by product of fishery industry, coated with carrageen edible. The method of this study of natural condimenent coated carrageen coating where assessed by trained panelis using by sensory attributes (odor, color appearance and taste). The result indicate potential of natural condiment for seasoning development. This research aims to be able to produce natural flavor that made from raw material of liquid waste of stew and coating with edible coating of carrageen. A natural flavor enhancer, as a food additive, needs to be done a hedonic organoleptic analysis to see the panelist's preference for natural flavorings. The results of a hedonic organoleptic test show that taste and odor are preferred over the texture and appearance of the natural flavorings.
\end{abstract}

Keyword: Juice water, by product,Natural Condiment, Edible Coating, Karagenana, Consumer Preference.

Produk samping (juice water) dari industry hasil perikanan yang belum dimanfaatkan secara optimal yaitu limbah cair yang dihasilkan pada saat perebusan ikan (pre-cooking). Perikanan yang berkelanjutan mengharuskan manusia mengelola sumberdaya alam dengan prinsip Zero Waste. Limbah cair hasil pengolahan ikan kebanyakan hanya dibiarkan ataupun dibuang ke laut yang mengakibatkan pencemaran bagi lingkungan. Limbah cair hasil rebusan ikan memiliki nilai gizi yang baik seperti protein, lemak yang dapat dimanfaatkan utuk penyedap rasa alamii. Penyedap rasa merupakan suatu bahan tambahan pangan yang sering digunakan dalam makanan yang bertujuan untuk menambah cita rasa ataupun hanya memperkuat cita rasa pada makanan. Penyedap rasa yang banyak dikomsumsi masyarakat yaitu MSG (Monosodium Glutamat) yang jika dikomsumsi secara berlebihan dapat mempengaruhi kesehatan. Penelitian ini bertujuan untuk dapat mendapatkan penyedap rasa alami yang dibuat dari bahan baku limbah hasil cair hasil rebusan ikan dan di-coating dengan edible coating dari karagenan. Penyedap rasa alami, sebagai bahan tambahan suatu makanan perlu dilakukan analisa organoleptik hedonik untuk melihat tingkat kesukaan panelis terhadap penyedap rasa alami. Hasil Pengujian organoleptik hedonik menunjukkan bahwa rasa dan bau lebihdisukaidibandingkan tekstur dan kenampakan dari penyedap rasa alami. Hal ini dikarenakan rasa dan bau yang dihasilkan dari asam glutamate pada penyedap rasa.

Kata kunci: Limbah cair, Penyedap Rasa Alami, Edible Coating, Karagenan, Organoleptik Hedonik.

\section{PENDAHULUAN}

Provinsi sulawesi utara merupakan salah satu daerah yang memiliki potensi ikan cakalang yang cukup banyak, hal ini dikarenakan letak geografisnya yang berhadapan dan berhubungan langsung degan lautan pasifik. Melimpahnya ikan Cakalang segar yang ada, mendorong banyak produsen mengolah ikan tersebut menjadi produk perikanan ekonomis, salah satunya pengolahan ikan Cakalang asap. Hasil olahan ikan asap ternyata banyak mengandung asam glutamate yang diketahui memiliki peran dalam cita rasa (Berhimpon, 2013).

Produksi pengolahan hasil perikanan yang dilakukan perusahaan atau industry berbasis rumah tangga menghasilkan limbah cair yang terutama disebabkan oleh proses pencucian ataupun perebusan. Perikanan yang berkelanjutan mengharuskan manusia mengelola sumberdaya alam dengan prinsip meminalisir tidak adanya limbah namun kenyataan $20-30 \%$ produksi perikanan dunia belum dimanfaatkan secara optimal. Limbah cair hasil pengolahan ikan kebanyakan hanya 
dibiarkan ataupun dibuang ke laut yang mengakibatkan pencemaran bagi lingkungan. Industri pengolahan ikan dan produk perikanan yang lain menghasilkan limbah cair dan padat yang belum dimanfaatkan secara optimal. Khususnya pada industri ikan cakalang asap PT. Celebes Minapratama yang merupakan industri pengolahan ikan kayu dimana dalam perebusan ikan merupakan salah satu tahapan dalam proses pengolahan ikan kayu sehingga menghasilkan limbah cair rebusan ikan sebanyak $15.000 \mathrm{~L}$ per hari. Limbah cair memiliki kandungan protein dan lemak yang belum diolah lebih lanjut (Berhimpon, 2013). Limbah cair yang dihasilkan dari sisa perebusan mempunyai kandungan gizi yaitu kadar protein $13,22 \%$, kadar lemak 2,10\%, kadar abu $2,60 \%$, kadar air $70,0 \%$ dan kadar garam $12,08 \%$ (Nurwahyunigsih, 2010).

Dewasa ini sebagian besar produk makanan yang beredar di masyarakat diolah menggunakan bahan tambahan pangan baik alami maupun sintetis. Penyedap rasa merupakan suatu bahan tambahan pangan yang sering digunakan dalam makanan yang bertujuan untuk menambah cita rasa ataupun hanya memperkuat cita rasa pada makanan tersebut. Perubahan dan perkembangan pada makanan mulai dari rasa hingga bentuk makanan semakin berkembang. Bermacammacam makanan hadir dan produsen makanan berlomba-lomba untuk menghasilkan makanan yang enak dan lezat untuk memenuhi kebutuhan konsumen. Bumbu-bumbu penyedap makanan diciptakan dengan tujuan agar olahan makanan menjadi lebih lezat (Juita $d k k, 2015$ )

Salah satu bahan tambahan pangan yang sering digunakan dalam pengolahan makanan adalah Monosodium Glutamat (MSG). Menurut Nuryani dan Jinap (2010), MSG merupakan garam natrium yang berikatan dengan asam amino berupa asam glutamat. Meskipun diperkenankan sebagai penyedap masakan, penggunaan MSG secara berlebihan bisa mengakibatkan rasa pusing dan mual (Chinese Restaurant Syndrome) dan kenaikan kadar garam dalam darah (Nuryani \& Kensaku 2006). Efek lain yang ditimbulkan diantaranya yaitu kanker, kerusakan sistem saraf dan mata, serta gangguan kehamilan dan janin (Sabri $d k k$, 2006). Preferensi masyarakat terhadap penggunaan penyedap rasa sangat tinggi walaupun sampai saat ini beberapa penyedap rasa yang ada di pasaran masih kontroversial sehingga perlu diteliti alternatif penyedap rasa alami dengan memanfaatkan hasil perikanan yang banyak mengandung asam glutamate.

Sebagian pengemas yang dikemas untuk makanan menimbulkan masalah bagi lingkungan, terutama yang terdiri dari bahan yang sulit mengalami biodegradasi, seperti plastik. Edible coating merupakan suatu bahan yang dapat befungsi sebagai pelapis produk serta memperpanjang masa simpan dan memperbaiki kualitas produk (Moga, 2017). Seperti halnya dengan pernyataan Christmas dkk. (2017), Edible coating dari karagenan memiliki sifat biodegradasi, bisa digunakan untuk menghambat/mengatur perpindahan uap air, oksigen, karbon dioksida, aroma, lipid dan juga sebagai pembawa bahan makanan untuk meningkatkan sifat-sifat dari makanan.

Limbah cair hasil rebusan ikan yang belum diolah secara maksimal dapat dimanfaatkan sebagai penyedap rasa alami yang aman dan sehat. Berdasarkan masalah tersebut penelitian ini bertujuan untuk dapat memproduksi penyedap rasa alami yang dibuat dari bahan baku limbah cair hasil rebusan ikan dari PT. Celebes Minapratama dan di-coating dengan edible coating dari karagenan. Penyedap rasa alami yang dibuat harus dilakukan pengujian organoleptik hedonik (tingkat kesukaan) yang menyatakan bahwa beberapa panelis menyukai atau tidak menyukai penyedap rasa tersebut yang dilihat melalui tekstur, aroma, kenampakan dan rasa. (Bawinto, 2015).

\section{METODE PENELITIAN}

\section{Bahan dan Alat}

Proses pengolahan dan pengujian untuk penyedap rasa alami membuthkan bahan dan alat yaitu sebagai berikut:

- Bahan pembuatan penyedap rasa alami Juice limbah ikan Cakalang (Air rebusan ikan) dari PT Celebes Minapratama sebanyak 5 liter, tepung maizena $1 \mathrm{~kg}$; garam $1000 \mathrm{~g}$; tomat $625 \mathrm{~g}$; jamur Shiitake $625 \mathrm{~g}$; bawang merah $312,5 \mathrm{~g}$; bawang putih $312 \mathrm{~g}$; gula semut $75 \mathrm{~g}$; tepung maizena $470 \mathrm{~g}$.

- Bahan pembuat edible coating:

Akuades 300ml Karagenan 2,5\% (7,5g); Tepung sagu $0,5 \%(1,5 \mathrm{~g})$; lilin lebah $0,4 \%$ $(1,2 \mathrm{~g})$; Gliserol $1 \% \quad(3 \mathrm{ml})$. Alat untuk pembuat edible coating adalah gelas ukur, beker glass, Homogenizer, spatula.

- Bahan untuk Analisa Organoleptik: 
Mie cup yang akan dicampurkan dengan penyedap rasa alami, air penetral.

- Alat pembuatan Penyedap Rasa Alami:

Alat untuk membuat penyedap rasa yaitu baki, pisau, blender, centongan, mangkuk besar 1 bowl, mangkuk panjang, saringan, telenan, wrapping, evaporator, sendok, timbangan.

- Alat untuk Pembuat Edible Coating

Gelas ukur, beker glass, Homogenizer, spatula.

- Alat untuk Pengujian Organoleptik

Sendok, wadah sampel, bilik pencicipan dan formulir penilaian.

\section{Prosedur Analisa Organoleptik Kesukaan (Hedonik) (Setyaningsih, 2010)}

Uji kesukaan juga disebut uji hedonik. Panelis dimintakan tanggapan pribadinya tentang kesukaan atau sebaliknya (ketidaksukaan). Disamping panelis mengemukakan tanggapan senang, suka atau kebalikannya, mereka juga mengemukakan tingkat kesukaannya. Tingkat-tingkat kesukaan ini disebut skala hedonik. Misalnya dalam hal "suka" dapat mempunyai skala hedonik seperti: amat sangat suka; sangat suka; suka; dan agak suka. Sebaliknya jika tanggapan itu "tidak suka" dapat mempunyai skala hedonik seperti suka dan agak suka, terdapat tanggapannya yang disebut sebagai netral, yaitu bukan suka tetapi juga bukan tidak suka. Skala hedonik dapat direntangkan atau diciutkan menurut rentangan skala yang dikehendakinya. Skala hedonik dapat juga diubah menjadi skala numerik dengan angka mutu menurut tingkat kesukaan. Dengan data numerik ini dapat dilakukan analisis secara statistik. Penggunaan skala hedonik pada prakteknya dapat digunakan untuk mengetahui perbedaan. Sehingga uji hedonik sering digunakan untuk menilai secara organoleptik terhadap komoditas sejenis atau produk pengembangan. Uji hedonik banyak digunakan untuk menilai produk akhir. Prosedur pengujian uji hedonik:

1. Persiapan 15 panelis terlatih;

2. Pengujian dilakukan secara individual dalam booth (bilik pencicip) yang disiapkan;

3. Persiapan penyedap rasa alami dan mie cup;

4. Buang bumbu pada mie cup dan diganti dengan penyedap rasa alami;

5. Panelis dipersilahkan masuk ke ruang pengujian setelah semua contoh uji siap diletakkan dalam bilik pencicipan;
6. Siapkan air penetral;

7. Panelis diminta menilai tingkat kesukaan terhadap (warna, bau, rasa dan kenampakan) dengan score sheet;

8. Selesai penilaian dilanjutkan dengan tabulasi data terhadap semua hasil penilaian.

\section{HASIL DAN PEMBAHASAN}

\section{Analisa Organoleptik Hedonik}

Analisa organoleptik merupakan suatu cara penilaian menggunakan indera manusia (sensori). Penilaian organoleptik merupakan cara yang paling banyak dilakukan dalam menentukan tingkat kesukaan panelis dari suatu pangan (Bawinto, 2015). Menurut Setyaningsih (2010), analisa organoleptik dengan uji hedonik dapat dilakukan menggunakan score sheet dengan skala dari 1 sampai 9, dimana angka 1 merupakan nilai terendah dan angka 9 sebagai nilai tertinggi. Penilaian uji hedonik dilakukan oleh panelis terlatih sebanyak 15 panelis yang terdiri dari mahasiswa yang sudah terlatih. Hasil yang diperoleh ialah sebagai berikut:

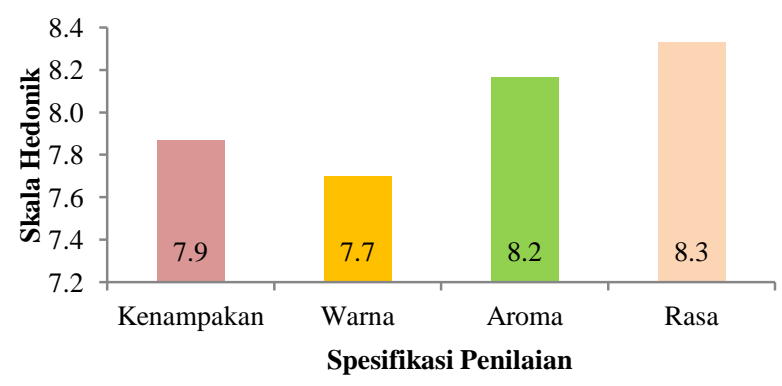

Gambar 1. Hasil Hasil Analisa Organoleptik Hedonik.

\section{Rasa}

Data hasil uji hedonik terhadap penyedap rasa alami yang telah diuji dengan menggunakan mie cup. Respon dari 15 panelis terhadap rasa didapatkan nilai rata-rata yaitu 8,3 yang berarti 15 panelis sangat suka terhadap rasa penyedap rasa alami. Rasa dari penyedap rasa alami paling disukai oleh panelis karena rasanya yang kuat dan enak, seperti yang diharapkan dari suatu penyedap rasa yang dapat memberikan rasa gurih dan menambahkan suatu cita rasa yang enak pada suatu makanan. sama halnya dengan penyedap rasa sintetik yang selama ini beredar di masyarakat. Menurut Sabri. $d k k$ (2006), bahwa penyedap rasa alami lebih menguntungkan untuk dikomsumsi karna memberikan tambahan nustrisi dan tidak memberikan dampak buruk bagi kesehatan. 


\section{Bau}

Data hasil uji hedonik terhadap bau penyedap rasa alami yang telah di uji dengan menggunakan mie cup. Respon 15 panelis terhadap bau didapatkan nilai rata-rata 8,1 yang berarti 15 panelis sangat suka terhadap bau dari penyedap rasa alami. Bau dari penyedap rasa alami disukai oleh panelis karena aromanya yang enak tetapi tidak terlalu kuat seperti penyedap rasa sintetik. Aroma dari suatu bahan pangan sangat berpengaruh terhadap reaksi tingkat kesukaan karena jika aroma suatu pangan yang mengandung asam glutamat akan mengelabuhi otak seakan telah merasakan sesuatu yang lezat (Mulyono, 2006).

\section{Warna}

Data hasil uji hedonik terhadap warna penyedap rasa alami yang telah diuji dengan menggunakan mie cup. Respon 15 panelis terhadap warna didapatkan nilai rata-rata 7,7 yang berarti panelis suka terhadap warna penyedap rasa alami. Warna penyedap rasa alami memberikan kesan suka dari panelis karena warna yang agak kecokelatan yang didapat dari jamur serta proses pengolahan.

\section{Kenampakan}

Data hasil hasil uji hedonik terhadap kenampakan penyedap rasa alami yang telah diuji dengan menggunakan mie cup. Respon 15 panelis terhadap kenampakan didapatkan nilai rata-rata 7,8 , yang berarti panelis suka terhadap kenampakan penyedap rasa alami. Sama halnya dengan warna kenampakan mendapatkan respon suka dari paneli. Kenampakan dari penyedap rasa dipengaruhi oleh proses pengolahan penyedap rasa alami dalam bentuk blok. Hal ini berbeda dengan penyedap rasa sintetik yang kebanyakaan dalam bentuk bubuk. Kelebihan penyedap rasa alami dalam bentuk blok yang di-coating yaitu dapat menahan penyerapan air dan oksigen yang dipengaruhi dari coating sehingga produk penyedap rasa alami tidak mudah mengalami penggumpalan karena setiap produk setelah diolah memiliki sifat higroskopis yaitu dapat menyerap air.

\section{KESIMPULAN DAN SARAN}

\section{Kesimpulan}

Dari hasil yang diperoleh dan dibahas maka dapat ditarik kesimpulan yakni hasil uji mutu organoleptik penyedap rasa alami dengan menggunakan metode uji hedonik atau tingkat kesukaan ialah rasa dan bau dari penyedap rasa sangat disukai oleh panelis dibandingkan dengan warna dan kenampakan dari penyedap rasa alami

\section{Saran}

Adapun hal yang perlu disarankan pada penelitian ini yaitu analisa organoleptik penyedap rasa alami perlu dilakukan pengujian hedonik terhadap masa simpan sehingga dapat dilihat juga tingkat kesukaan panelis pada produk penyedap rasa alami untuk masa simpan yang berbeda.

\section{DAFTAR PUSTAKA}

Afriani, UR, 2007, Kajian Etnobotani dan Aspek Konservasi Sengkubak (Pcynarrhenacauliflora (Miers.) Diels.) di KabupatenSintang Kalimantan Barat, Tesis sekolahPascasarjana IPB, Bogor.

Berhimpon, S., Montolalu, R.I., Dien, H.A., Mentang, F., dan Sendow, G.M.2013. Produksi dan Komersialisasi Penyedap Rasa Alami Kaya Iodium Berbasis Ikan Asap Serta Pemanfaatan Biopolimer Dari Limbah Industri Perikanan Sebagai Edible Sachet. Proposal Riset. Program Bantuan Dana Riset InovatifProduktif. Lembaga Pengelolaan Dana Pendidikan (RISPRO LPDP). Lembaga Penelitian Universitas Sam Ratulangi. Manado.

Berhimpon, S., Montolalu, R.I., Dien, H.A., Mentang, F., dan Sendow, G.M. 2015. Produksi dan Komersialisasi Penyedap Rasa Alami Kaya Iodium Berbasis Ikan Asap Serta Pemanfaatan Biopolimer dari Rumput Laut dan Limbah Industri Perikanan Sebagai Edible Sachet Film. Laporan Akhir Kegiatan. Program Bantuan Dana Riset Inovatif-Produktif Lembaga Pengelolaan Dana Pendidikan (RISPRO LPDP). Lembaga Penelitian dan Pengabdian Kepada Masyarakat. Universitas Sam Ratulangi. Manado.

Bawinto, A.S., Mongie, E., dan Kasanger, B. E. 2015. Analisa Kadar Air, pH, Organoleptik dan Kapang Pada Produk Ikan Tuna (Thunnus Sp) Asap, di Kelurahan Girian Bawah Kota Bitung, Sulawesi Utara. Universitas Sam Ratulangi, Manado. Jurnal Media Teknologi Hasil Perikanan.

Bariah, E, I., Berhimpon, dan S., Mongi, L, E. 2015. Krakteristik Organoleptik Otak Otak Ikan Yang diberi Edible Coating Karaginan dengan Penambahan Asap Cair. Jurnal Media Teknologi Hasil Perikanan.

Chavan, B.R., Basu, S., and Kovale, S.R. 2008. Development of edible texturised driedfish granules from low-value fish croaker (Otolithus argenteus) and its storage characteristics. J Nat Sci. 7 (1): 173.

Christmas, T., Berhimpon, S., Montolalu, R, I., Dien, H, M., dan Mentang, F. 2017. Karaktersitik Fisik Edible Film Komposit Karagenan dan Lilin Lebah Menggunakan Proses Nanoemulsi. Program Studi Magister Ilmu Perairan. Fakultas Perikanan dan Ilmu Kelautan. Universitas Sam Ratulangi, Manado. Jurnal Pengolahan Hasil Perikanan Indonesia.

Juita, N., Lovardi I., dan Linda, L. 2015. Pemanfaatan Tumbuhan Penyedap Rasa Alami pada Masyarakat 
Suku Dayak Jangkang Tanjung dan Melayu di Kabupaten Sanggau. Universitas Tanjungpura. Jurnal Media Teknologi Hasil Perikanan.

Moga T, Montolalu RI, Berhimpon S, Mentang F. 2017. Karakteristik edible film dari karagenan dengan penambahan asap cair dan aplikasinya sebagai coating pada sosis dan bakso ikan. Jurnal Aquatic Science \& Management (in press.).

Nuryani H \& Jinap S. 2010. Soy Sauce and Its Umami Taste: A Link From the Past.

Nuryani H \& Kensaku T. 2006. Evaluationof Peptide Contribution to the IntenseUmami Taste of Japanese Soy Sauces. Journal of Food Science 71(3): 277-283.

Nurwahyuningsih, V. 2010. Pemanfaatan Air Rebusan Ikan Tongkol (Euthynnus affis) Sebagai Bahan Pembuatan Kerupuk. Institut Pertanian Bogor.

Sabri , E, Supriharti, D \& Gunawan E, U. 2006. Efek pemberian monosodium glutamate (MSG) terhadap perkembangan embriomencit (Mus musculus L.) strain DDW selama periode pra implantasi hingga organogenesis, Jurnal Biologi Sumatera, vol. 1, no. 1, hal. 8-14.
Setiawati SN. 2008. Dampak Penggunaan Monosodium Glutamat terhadap Kesehatan Lingkungan. Jurnal Orbith 4 (3): 453-459.

Santoso, B. H. 1989.Jahe. Kanisius. Yogyakarta.

Setyaningsih, Dwi., Aprianto, Anton., dan Sari, Maya, P. 2010. Analisis Sensosi untuk Industri Pangan dan Agro. Penerbit, IPB Press. Kampus IPB Kencana, Bogor.

Wibowo S. 2000. Industri Pemindangan Ikan. Penebar Swadaya. Jakarta.

Widowati, S., Herwati, H. Syarief R., Suyatma, N, E., dan Prasetia, H, A. 2010. Pengaruh Isotermi Sorpsi Air Terhadap Stabilitas Beras Ubi. Jurnal Teknologi dan Industri Pangan. Institut Pertanian Bogor.

Widyastuti, Netty., Donowati, Tjokrokusumo dan Reni, Giarni. 2016. Potensi Beberapa Jamur Basidiomycota Sebagai Bumbu Penyedap Alternatif Masa Depan. LAPTIAB-Pusat Teknologi Bioindustri.

Widyalita, Eka, P., Saifuddin,S., dan Zakaria. 2015. Analisis Kandungan Monosadium Glutamat (MSG) Pada Pangan Jajanan Anak Di Sd Komp. Lariangbangi Makassar. Ilmu Gizi Fakultas Kesehatan Masyarakat Universitas Hasanuddin. Makassar. 